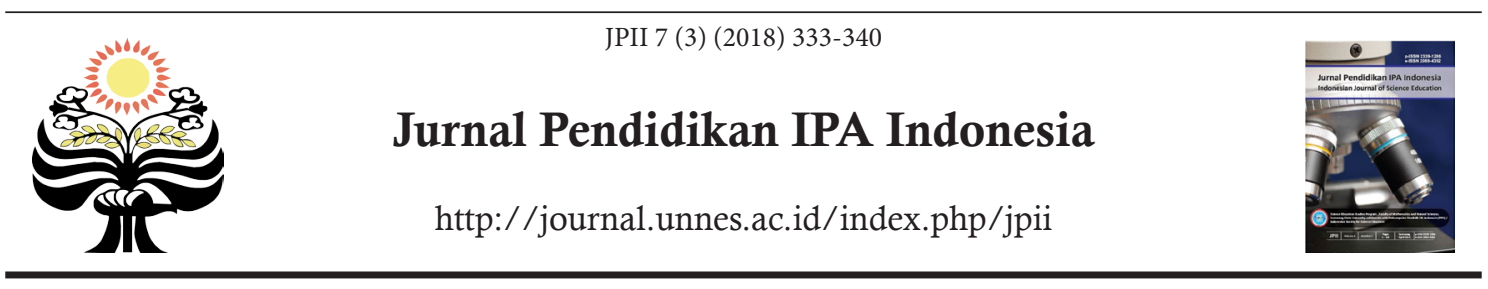

\title{
INCOMPLETE EXPLANATION IN DETERMINING OXIDATION NUMBER: A CASE STUDY ON CHEMISTRY PROGRAM STUDENTS
}

\author{
R. Basuki ${ }^{* 1}$, H. Amanda ${ }^{2}$, R. Bemis ${ }^{3}$, A. Lisma ${ }^{4}$, Yusnaidar ${ }^{5}$ \\ ${ }^{1,2}$ Department of Chemistry, Faculty of Science and Technology, Universitas Jambi \\ ${ }^{3}$ Research Group of Material Engineering, Faculty of Science and Technology, Universitas Jambi \\ ${ }_{4,5}$ Instruments and Research Laboratory, Faculty of Science and Technology, Universitas Jambi
}

DOI: 10.15294/jpii.v7i3.13251

Accepted: February $2^{\text {nd }}, 2018$. Approved: August 31 $1^{\text {st }}, 2018$. Published: September $20^{\text {th }}, 2018$

\begin{abstract}
The term "oxidation number" and related concept such as "electronegativity" and "formal charge" appear frequently in both elementary and advance chemistry text. However, it is evident from the literature (or textbooks) that these terms are often viewed to be synonymous. Incomplete explanation of the fundamental concept of oxidation number can lead that conclusions pertaining to such a misleading interpretation. This research was conducted to review the concepts from common used high school chemistry textbooks and these concepts were then transformed to 6 number open minded problems. These problems were then tested to 40 first semester chemistry program students in the University of Jambi who joining Basic Chemistry course. The result was about $80 \%$ of students give the right answer in determining oxidation number (problem number 1). But, in the certain molecule (problem number 2) they can't determine correctly because they couldn't use the "Rule" from initial understanding in high school. For the next problem (4a), none of the students give the right oxidation number of an atom and all of them can't explain precisely correlation among oxidation number, electronegativity, and formal charge. The intent of this paper is to clarify the notion of oxidation number, electronegativity, and formal charge, describe their relationship (especially for high school chemistry textbooks), and criticize upon misleading application.
\end{abstract}

(C) 2018 Science Education Study Program FMIPA UNNES Semarang

Keywords: incomplete explanation, determining oxidation number, case study, chemistry program student

\section{INTRODUCTION}

In the history of chemistry, one of the most vehement disputes concerned the nature of oxidation (Weisberg, et al. 2011; Sunarya 2009; Utami et al, 2009). In 1718, Georg Stahl, a German chemist, studied the formation of metals from oxides by heating the oxide with charcoal (carbon). He proposed that the formation of metal was caused by a substance, called "phlogiston." According to Stahl, the converse process of heating a metal in the air to form its oxide caused the release of phlogiston into the atmosphere (Sukopp, 2018). Fifty-four years later, the French chemist, Louis-

*Correspondence Address

E-mail: rhmtbsq@gmail.com
Bernard Guyton de Morveau performed careful experiments showing that, during combustion, metals increase in weight. However, the existence of phlogiston was so well established among chemists that he interpreted the results as meaning that phlogiston had the negative weight (Chang, 2010; Watoni, 2016). It was his colleague, Antoine Lavoisier, who was willing to throw out the phlogiston concept and propose that combustion was due to the addition of oxygen to the metal (oxidation) and the formation of a metal from an oxide correspondent to the loss oxygen (reduction) (Stadler \& Harrowfielda, 2011; Sudarmo \& Sariawati 2015). This concept was well-known as "redox" concept and the most ancient concept of redox. 
Common used high school chemistry textbooks often attached development concept of redox from the ancient to the modern concept (Table 1). However, at the current time, both in elementary until advance level, the most concept has been used to explain the related concept in chemistry course is redox involved oxidation number $(\mathrm{ON})$. From this concept, oxidation defines as increasing of $\mathrm{ON}$, and reduction is decreasing of ON. Determining ON in high school first taught in grade $\mathrm{X}$ after they learn chemical bonding, atomic theory, and the periodic table of elements. Most of the commonly used chemistry text books using "the rules" approach to determine ON, without connection with the previous chapter (Österlund, et al. 2010; Permana, 2009). Besides, the fundamental concept of determining $\mathrm{ON}$ was much related to the previous concept.

Table 1. Redox Concept Definition from Ancient to the Modern Concept

\begin{tabular}{ll}
\hline \multicolumn{1}{c}{ Oxidation } & \multicolumn{1}{c}{ Reduction } \\
\hline Gaining oxygen & Loosing oxygen \\
Loosing hydrogen & Gaining hydrogen \\
Loosing electron & Gaining electron \\
Increasing ON & Decreasing ON \\
\hline
\end{tabular}

Incomplete explanation of determining ON can result in misleading interpretations or misconception (Widarti et al, 2016; Harnanto \& Ruminten 2009). Redox material misconception had been experienced by students (Rosenthal \& Sanger, 2012; Al-Balushi et al, 2012; Setyawati, 2009) for example: they had a difficulty in distinguishing the definition of the oxygen and electrons transfer, they often experience an error in the determination of the oxidation number of atom in molecule, they did not know the key concept of oxidation and its relation to another concept i.e. electronegativity; and also they had a difficulty on how to apply the equalization to equalize the redox reactions. Misleading interpretation on determining ON will affect the students in the understanding and application of redox concept (Brandriet \&Bretz, 2014; Muchtariadi, 2016; Purba 2015).

Determining ON matter in high school the first time studied in grade $\mathrm{X}$ after they learn chemical bonding, atomic theory, and the periodic table of element. Common high school chemistry textbook was using the "Rules" approach to determining ON. This "Rules" worked in some simple molecule, such as $\mathrm{HCl}, \mathrm{HNO}_{3}, \mathrm{H}_{2} \mathrm{SO}_{4}$, $\mathrm{H}_{3} \mathrm{PO}_{4}$, etc. But, for a more complex molecule or even simple organic molecule $\left(\mathrm{ICl}_{5}, \mathrm{CH}_{3} \mathrm{COOH}\right.$,
$\mathrm{C}_{2} \mathrm{H}_{5} \mathrm{OH}, \mathrm{Na}_{2} \mathrm{~S}_{2} \mathrm{O}_{4}, \mathrm{POBr}_{3}, \mathrm{H}_{2} \mathrm{O}_{2}$, etc.) the "Rules" didn't work well. This phenomenon carried from high school to universities. In universities the chain of incomplete explanation of redox concept must be broken, especially through the Basic Chemistry Course. This paper aimed to give a better understanding of determining ON through complete explanation of the $\mathrm{ON}$ fundamental concept. Furthermore, the differences and their relation of ON concept with electronegativity, formal charge and the concept of valence were also critically discussed in this paper.

\section{METHODS}

This research employed the descriptive analysis study in the form of case study research. Forty students of Chemistry Program in the first semester (2017/2018) of University of Jambi were studied. They joined the Basic Chemistry course subject. The research instrument was an open answer test adapted from some commonly used chemistry textbook in Indonesia (Table 2). The textbook code A to E is an e-book published by Bookkeeping Center of the Ministry of National Education (Pusbuk) as Electronic School Book (ESB) which based on author's experience it is still used as a learning source for High School students. The textbook F to I is a printed textbook which very easy to find because it was available in any bookstore in Indonesia.

Six open answers problems (Table 3 ) and the analysis of problem choice were given in the test before entering the Redox Reaction chapter (pre-test). The answer given by the students was a reflection of their thinking ability and their understanding of the concept learned before (in high school).

Table 2. Common Used Chemistry Textbooks as a Source of Instrument Research Problems

\begin{tabular}{ll}
\hline Code & \multicolumn{1}{c}{ Textbook Identity } \\
\hline A & Setyawati, A.A. (2009). Pusbuk ESB \\
B & Permana, I. (2009). Pusbuk ESB \\
C & Sunarya, Y \& Setiabudi, A. (2009) Pusbuk \\
& ESB \\
D & Utami, D et al., (2009). Pusbuk ESB \\
E & Harnanto, A. \& Ruminten. (2009). pusbuk \\
& ESB \\
F & Sudarmo, U. \& Sariwati, E. (2015). Erlangga \\
G & Purba. M. (2015). Erlangga \\
H & Muchtariadi. (2016). Yudhistira \\
I & Watoni, H., Kurniawati, D., \& Juniastri, M. \\
& (2016). Yrama Widya \\
\hline
\end{tabular}




\section{RESULTS AND DISCUSSION}

\section{Determining the Oxidation Number}

As stated before, common used high school chemistry textbooks use the "Rules" for determining ON. Here is a summary of these "Rules" from common used high school chemistry textbooks:

(1) ON of free atom is zero;

(2) Sum of ON in a neutral atom is zero;

(3) ON of monoatomic ion is equal to its charge;

(4) Sum of $\mathrm{ON}$ in a polyatomic ion is equal to its charge;

(5) ON of oxygen atom generally is -2 , but it is -1 in peroxide, and $-1 / 2$ in superoxide;

(6) $\mathrm{ON}$ of hydrogen atom generally is +1 , but it is +1 in hydride;
(7) $\mathrm{ON}$ of another atom, determined from its group, such as group IA generally is +1, IIA is +2 , IIIA is +3 , VIIA generally is -1 etc.

It is mention in these textbooks some example of an atom in a molecule that the $\mathrm{ON}$ would be determined: "Determine the ON of $\mathrm{S}$ (sulfur) atom in $\mathrm{H}_{2} \mathrm{SO}_{4}$ !". Using rule number (2), (5), and (6), the calculation can be express:

$(2 \times \mathrm{ON}$ of $\mathrm{H})+(1 \times \mathrm{ON}$ of $\mathrm{S})+(4 \times \mathrm{ON}$ of $\mathrm{O})=0$

$(2 \times+1)+(\mathrm{ON}$ of $\mathrm{S})+(4 \times-2)=0$

$(+2)+\mathrm{ON}$ of $\mathrm{S}+(-8)=0$

$\mathrm{ON}$ of $\mathrm{S}=+6$

The other example that can be solved using the "rules" were $\mathrm{KMnO}_{4}, \mathrm{NaCl}, \mathrm{K}_{2} \underline{\mathrm{Cr}}_{2} \mathrm{O}_{7}, \mathrm{HNO}_{3}$, $\mathrm{H}_{3} \mathrm{PO}_{4}, \underline{\mathrm{SO}}_{3}, \underline{\mathrm{Fe}}_{2} \mathrm{O}_{3}, \underline{\mathrm{V}}_{2} \mathrm{O}_{5}$, etc. (the underlined atom was atom will be determined its $\mathrm{ON}$ ).

Table 3. The Problems Summary Adapted from Common Used High School Chemistry Textbooks

\begin{tabular}{llll}
\hline Num. & \multicolumn{4}{c}{ Problem } & \multicolumn{1}{c}{ Analysis } \\
\hline 1 & $\begin{array}{l}\text { Determine the oxidation number of each atom in the } \\
\text { molecule below! }\end{array}$ & $\begin{array}{l}\mathrm{C} \text { Level. ON of each atom of this } \\
\text { molecule can be easily determined } \\
\text { by "The Rules". }\end{array}$ \\
$\begin{array}{lllll}\mathrm{a} \mathrm{HO}_{3} & \text { b. } \mathrm{Fe}_{2} \mathrm{O}_{3} & \text { c. } \mathrm{KMnO}_{4} & \text { d. } \mathrm{K}_{2} \mathrm{Cr}_{2} \mathrm{O}_{7} & \\
\mathrm{H}: & \mathrm{Fe}: & \mathrm{K}: & \mathrm{K}: \\
\mathrm{N}: & \mathrm{O}: & \mathrm{Mn}: & \mathrm{Cr}: \\
\mathrm{O}: & \mathrm{O}: & \mathrm{O}:\end{array}$
\end{tabular}

2 Determine the oxidation number of each atom in the molecule below!

$\begin{array}{llll}\text { a. } \mathrm{KO}_{2} & \text { b. } \mathrm{NaH} & \text { c. } \mathrm{H}_{2} \mathrm{O}_{2} & \text { d. } \mathrm{OF}_{2} \\ \mathrm{~K}: & \mathrm{Na}: & \mathrm{H}: & \mathrm{O}: \\ \mathrm{O}: & \mathrm{H}: & \mathrm{O}: & \mathrm{F}:\end{array}$

C3 Level. "The Rules" still partly applied, but the student starts to confuse especially to determine the $\operatorname{sign}(+)$ or $(-)$.

3 Based on what theory you choose each oxidation number in problem number 2 ?

C4 Level. The students should explain based on what thy choose $(+)$ or (-) sign in ON.

4 Determine the oxidation number of each atom in the C4 Level. "The Rules" completely molecule below!

$\begin{array}{llll}\text { a. } \mathrm{S}_{3} \mathrm{O}_{2}{ }^{2-} & \text { b. } \mathrm{POBr}_{3} & \text { c. } \mathrm{CH}_{3} \mathrm{COOH} & \text { d. } \mathrm{ICl}_{5} \\ \mathrm{~S}: & \mathrm{P}: & \mathrm{C}: & \mathrm{I}: \\ \mathrm{O}: & \mathrm{O}: & \mathrm{H}: & \mathrm{Cl}: \\ & \mathrm{Br}: & \mathrm{O}: & \end{array}$
can't be used. ON determined by Lewis structure interpretation and electronegativity concept.

5 Based on what theory you choose each oxidation number in problem number 4 ?

6 Determine the formal charge for each atom in problem number 4 ! Can you explain the nature of formal charge compares with oxidation number?

$\begin{array}{llll}\mathrm{S}: & \mathrm{P}: & \mathrm{C}: & \mathrm{I}: \\ \mathrm{O}: & \mathrm{O}: & \mathrm{H}: & \mathrm{Cl}: \\ & \mathrm{Br}: & \mathrm{O}: & \end{array}$

C4 Level. The students should explain based on what thy choose $(+)$ or (-) sign in $\mathrm{ON}$.

C4 Level. Formal Charge is "ownership" of an electron if shared evenly. In high school FC has almost never been introduced. 
The results of problem 1 appear in Figure 1. These results indicated the good understanding of some molecule that its ON can be solved by the "Rules". The wrong answers were caused by mistake assumption that $\mathrm{ON}$ belongs to a group of the atom. The right concept was ON belongs to only a single atom. The percentage of the right answers to problem 1 can be seen in Figure 1 .

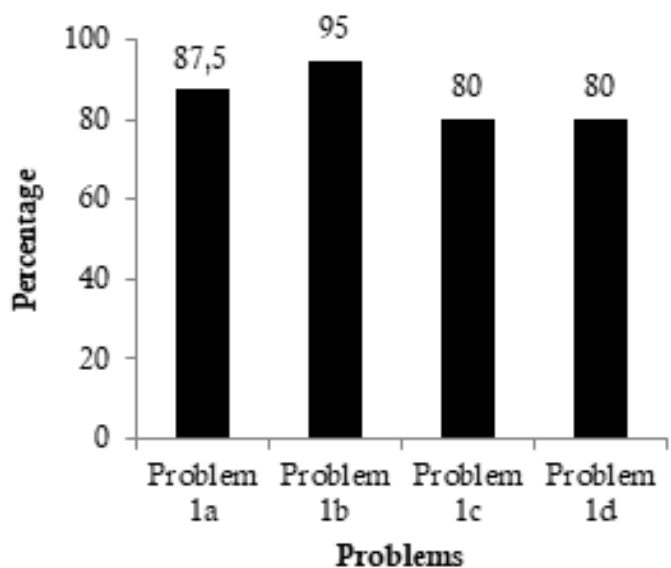

Figure 1. The Right Answers Percentage of Problem 1

Overall, the right answers percentage above $80 \%$, so problem 1 successfully solved using "The Rules".

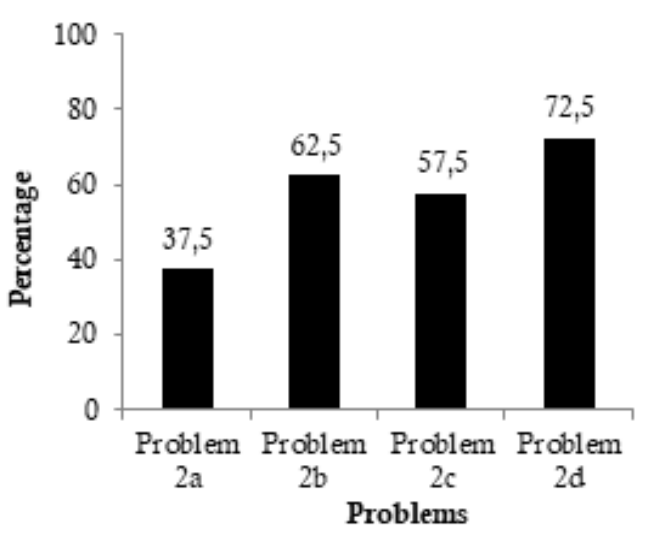

Figure 2. The Right Answers Percentage of Problem 2

\section{The Correlation of ON, Chemical Bonding, and Electronegativity}

The problems emerged when the students try to solve Problem 2. They were confused determined $\mathrm{ON}$ of each atom especially its sign, $(+)$ or (-). Even tough, almost $50 \%$ give the right answers, but them just guessing. They haven't a fundamental concept to confirm their results. This proven by them that they can't answer Problem 3. Some students answer "Exceptional", but still, they didn't know for sure when using "exceptional" and "common" one.

Table 4. Electronegativity of Pauling Scale Several Selected Atoms (Mann, et al. 2000)

\begin{tabular}{|c|c|c|c|c|c|c|c|c|}
\hline 1 & 2 & 12 & 13 & 14 & 15 & 16 & 17 & 18 \\
\hline $\begin{array}{l}\mathrm{H} \\
2.300\end{array}$ & & & & & & & & $\begin{array}{l}\mathrm{He} \\
4.160\end{array}$ \\
\hline $\begin{array}{l}\mathrm{Li} \\
0.912\end{array}$ & $\begin{array}{l}\mathrm{Be} \\
1.576\end{array}$ & & $\begin{array}{l}\text { B } \\
2.051\end{array}$ & $\begin{array}{l}\mathrm{C} \\
2.554\end{array}$ & $\begin{array}{l}\mathrm{N} \\
3.066\end{array}$ & $\begin{array}{l}\mathrm{O} \\
3.610\end{array}$ & $\begin{array}{l}F \\
4.193\end{array}$ & $\begin{array}{l}\mathrm{Ne} \\
4.787\end{array}$ \\
\hline $\begin{array}{l}\mathrm{Na} \\
0.869\end{array}$ & $\begin{array}{l}\mathrm{Mg} \\
1.293\end{array}$ & & $\begin{array}{l}\mathrm{Al} \\
1.613\end{array}$ & $\begin{array}{l}\mathrm{Si} \\
1.916\end{array}$ & $\begin{array}{l}\mathrm{P} \\
2.253\end{array}$ & $\begin{array}{l}S \\
2.589\end{array}$ & $\begin{array}{l}\mathrm{Cl} \\
2.689\end{array}$ & $\begin{array}{l}\mathrm{Ar} \\
3.242\end{array}$ \\
\hline $\begin{array}{l}\mathrm{K} \\
0.734\end{array}$ & $\begin{array}{l}\mathrm{Ca} \\
1.034\end{array}$ & $\begin{array}{l}\mathrm{Zn} \\
1.588\end{array}$ & $\begin{array}{l}\mathrm{Ga} \\
1.756\end{array}$ & $\begin{array}{l}\mathrm{Ge} \\
1.994\end{array}$ & $\begin{array}{l}\text { As } \\
2.211\end{array}$ & $\begin{array}{l}\mathrm{Se} \\
2.424\end{array}$ & $\begin{array}{l}\mathrm{Br} \\
2.685\end{array}$ & $\begin{array}{l}\mathrm{Kr} \\
2.966\end{array}$ \\
\hline $\begin{array}{l}\mathrm{Rb} \\
0.706\end{array}$ & $\begin{array}{l}\text { Sr } \\
0.963\end{array}$ & $\begin{array}{l}\mathrm{Cd} \\
1.521\end{array}$ & $\begin{array}{l}\text { In } \\
1.656\end{array}$ & $\begin{array}{l}\mathrm{Sn} \\
1.824\end{array}$ & $\begin{array}{l}\mathrm{Sb} \\
1.984\end{array}$ & $\begin{array}{l}\mathrm{Te} \\
2.158\end{array}$ & $\begin{array}{l}\text { I } \\
2.359\end{array}$ & $\begin{array}{l}\mathrm{Xe} \\
2.582\end{array}$ \\
\hline $\begin{array}{l}\text { Cs } \\
0.659\end{array}$ & $\begin{array}{l}\mathrm{Ba} \\
0.881\end{array}$ & $\begin{array}{l}\mathrm{Hg} \\
1.765\end{array}$ & $\begin{array}{l}\mathrm{T} 1 \\
1.789\end{array}$ & $\begin{array}{l}\mathrm{Pb} \\
1.854\end{array}$ & $\begin{array}{l}\mathrm{Bi} \\
(2.01)\end{array}$ & $\begin{array}{l}\text { Po } \\
(2.19)\end{array}$ & $\begin{array}{l}\text { At } \\
(2.39)\end{array}$ & $\begin{array}{l}\mathrm{Rn} \\
(2.60)\end{array}$ \\
\hline
\end{tabular}

Problem 2 shows us that $\mathrm{ON}$ is very related to another concept. The concepts that so related with $\mathrm{ON}$ were electronegativity and chemical bonding. The definition by its terminology of $\mathrm{ON}$ is the charge remaining on an atom when all ligands are removed heterolytically in their closed form, with the electron being transferred to the more electronegative partners; homonuclear bonds do not contribute to the ON (Parkin, G., 2006). Table 4. shows the value of electronegativity by Pauling scale on several selected atom (Jensen, 2012; Chattaraj \& Duley, 2010).
From the explanation of redox definition above, it can conclude two things; first, ON can be determined from differences between electronegativity values. It was because the differences in electronegativity values lead to the type of chemical bonds. If the differences were great, the substance tends to ionic, otherwise if slight, it tends to covalent. The level of ionic character can be determined by calculation of moment dipole (Miessler et. al., 2014) and covalent character can be determined by Fajans Rule i.e. calculation of charge density/polarization of molecule (Can- 
ham \& Overton, 2010). Based on both methods, there is no molecule with $100 \%$ of ionic/covalent character. The term ionic/covalent compound means it has greater ionic/covalent, not pure ionic/covalent compound (Wells, 2012; Diercks \& Yaghi, 2017).

The second, ON concept is designated for a substance that has wide electronegative differences, thus, the substance assumed tend to ionic. These electronegative differences cause the heterolytic cleavage, where the electron will give to the atom with greater electronegativity. If the atom in substance has the same electronegativity, so the substance tends to covalent and cause the homolityc cleavage, where the electron will be share equally to each atom/ligands. This condition obtains a new unit called a formal charge (FC). The calculation of $\mathrm{ON}$ and FC can be seen below (Figure 3).

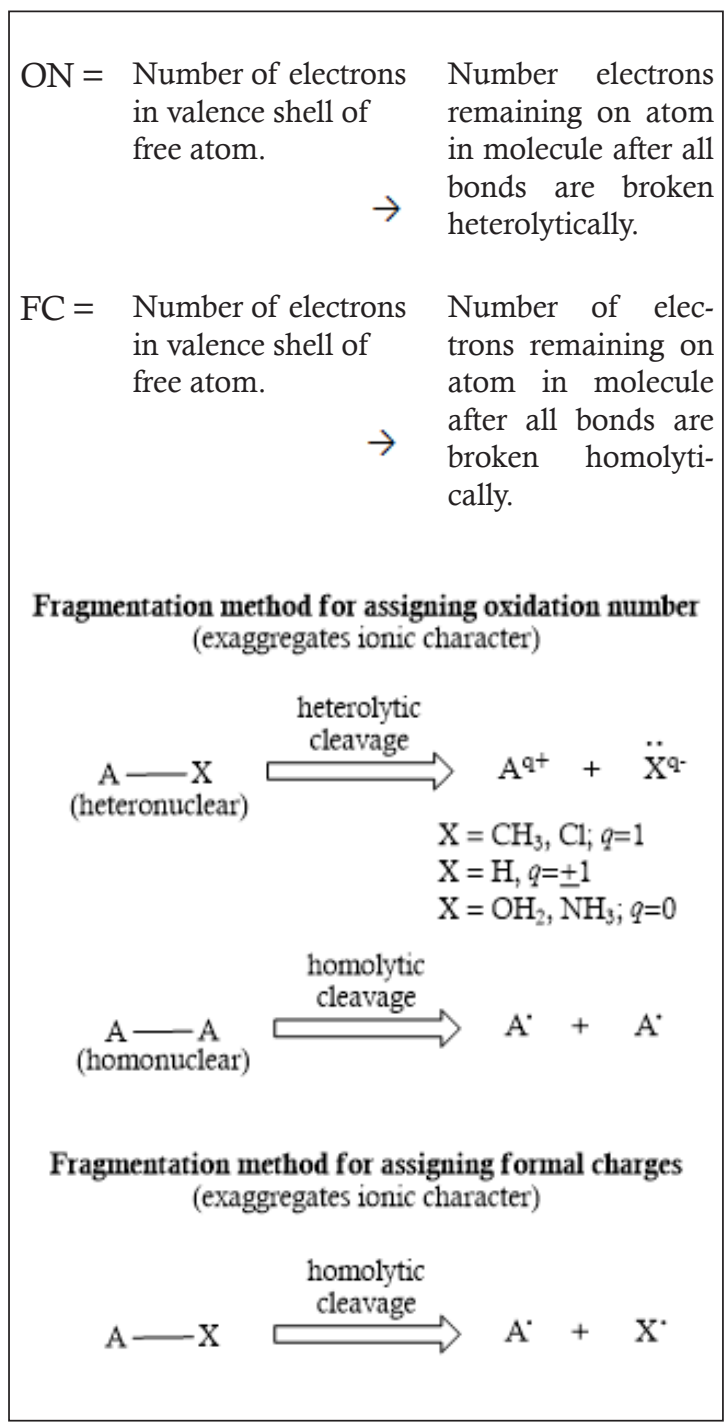

Figure 3. Fragmentation Methods for Assigning the Oxidation Number and the Formal Charge.
Determining ON based on this concept requires drawing the Lewis structure (electron-dot) that molecule. Whereas, an electron in covalent polar bond is not fully shared together, to simplify the $\mathrm{ON}$ calculation it is assumed that electron "belong to" atom with greater electronegativity. Example of determining some common compound can be seen in Figure 4.

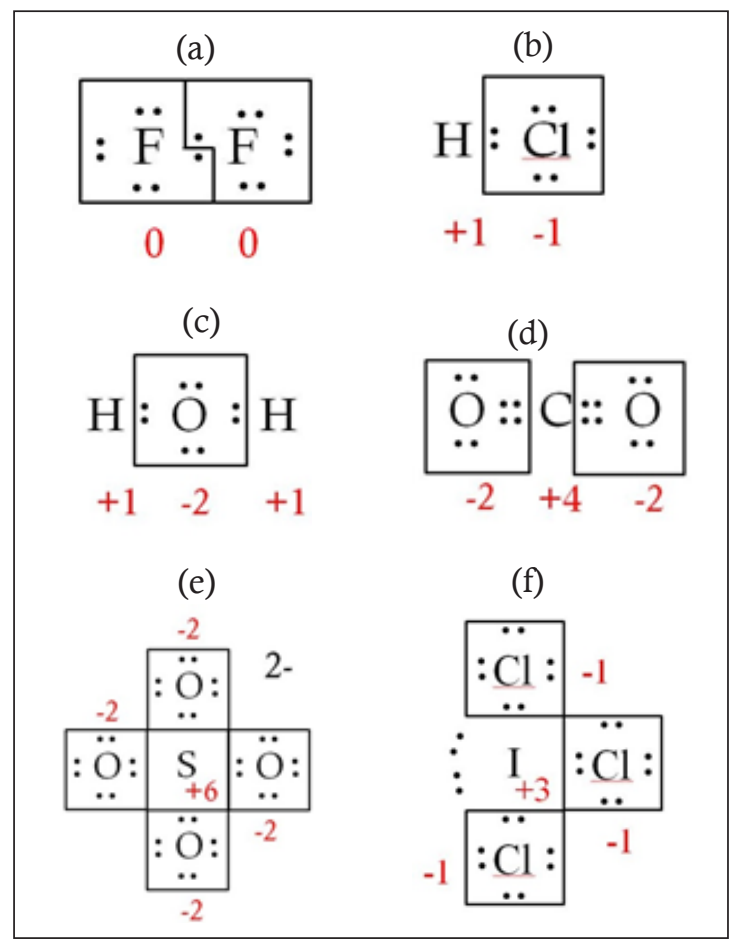

Figure 4. Determining ON of Some Common Compounds by Heterolytic Cleavage

Figure 4(a) explains why the free molecule has $\mathrm{ON}$ zero. Fluorine atom in the $\mathrm{F}_{2}$ molecule has the same electronegativity, so will be a homolitycal cleavage, where electron shared equally. So, $\mathrm{ON}$ of both $\mathrm{F}$ atom can be count as $7-7=$ 0 . The same principle can be applied to Figure 4 (b) to (f) that electron as if "belong to" the more electronegative atom. Then, the right answer of problem number 3 and 5 was "electronegativity". Only $15 \%$ (6 students) give the right answer, the rest of them reply with "because of the rule" answers.

From the explanation presented in Figure 4 , we can determine ON compound in problem 4 correctly (Figure 5 ). The bond symbolized by line (-) means the pairs of the electron. The right answers percentage of Problem 4 shows in Figure 6. The entire students think that $\mathrm{ON}$ of sulfur atom in $\mathrm{S}_{2} \mathrm{O}_{3}{ }^{2-}$ ion (Figure 5a) has the same value, +2 . Using "The Rules" they count $2 \times(\mathrm{ON} \mathrm{S})+$ $2 \times(-2)=-2$. This calculation can't be accepted because each of sulfur has a different environment. 
ON of S (center) has only 1 electron left because it is bonding with 3 oxygen atoms which have a higher electronegativity than $\mathrm{S}$ and $1 \mathrm{~S}$ atom which have equal electronegativity. So, calculation can be written ON S (center) $=6-1=+5$, for $\mathrm{S}$ (side) $\mathrm{ON}=6-7=-1$. Calculation of FC (Problem 6) cannot be answered correctly by all students. The FC sound so strange in students because FC concept was not introduced in high school (Loock, 2010). All students confirm that there is no explanation about FC in the previous place (high school or university). In high school (or university) FC can be taught related to VSEPR topics (Taber, 2013).

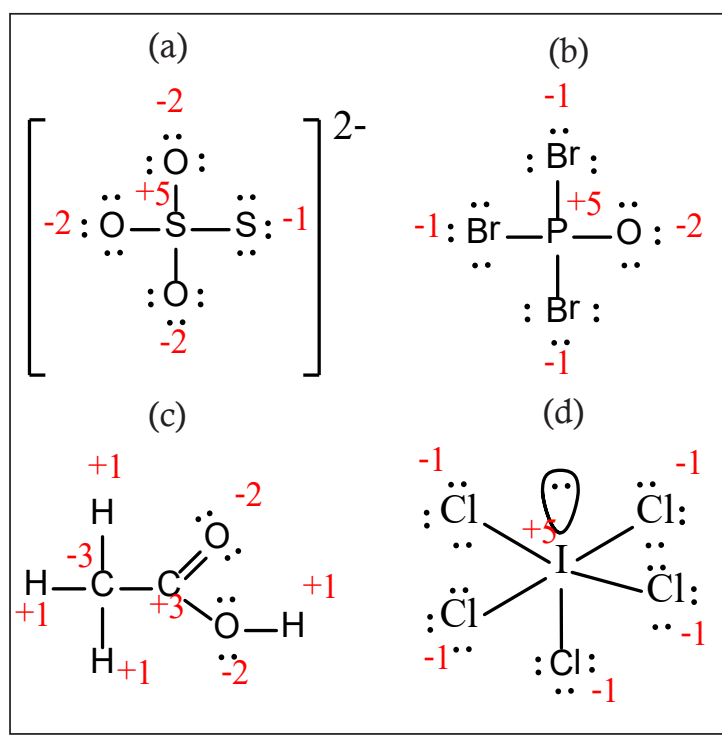

Figure 5. The $\mathrm{ON}$ of an Atom in the Molecule at Problem 4

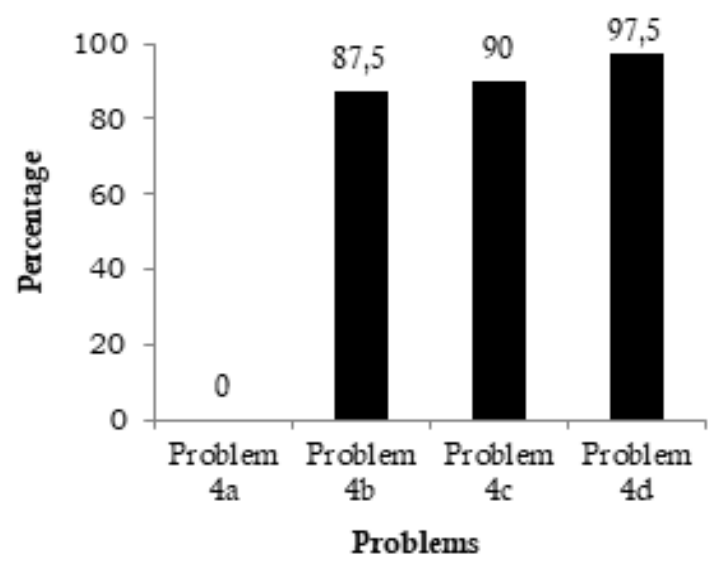

Figure 6. Right Answers Percentage of Problem 4

Memorizing "The Rules" for determining ON was not so helpful if the deal with the more complex compound. Some compound only can be determined the $\mathrm{ON}$ by the combination of Le- wis structure and electronegativity. Using "the rules" to determine ON of complex compound can lead to mistake knowledge and misconception (Regan et al, 2011). From 9 common high school chemistry textbooks (Table 2), only 2 books provide the information of electronegativity to determine ON. However there was still had some mistakes in the example. Here is some common compound in some textbook which often mistakes in determining of ON (Figure 7).
(a) $\mathrm{PH}_{3}$
(b) $\mathrm{PH}_{4} \mathrm{Br}$

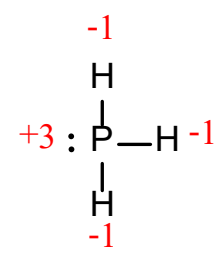

(c) $\mathrm{N}_{2} \mathrm{H}_{4}$

d) $\mathrm{NaH}$

$+1 \mathrm{H}-\underset{\mathrm{N}}{\stackrel{-\mathrm{N}}{-}}-\stackrel{\mathrm{N}}{\left.\right|_{+1} ^{+}}-\mathrm{H}^{+1}$

$+1 \quad-1$

$\mathrm{Na}: \mathrm{H}$

(e) $\mathrm{H}_{2} \mathrm{O}_{2}$<smiles>C1CCCCC1</smiles>
$-1 \quad-1$<smiles>[1H]O[Hg]</smiles>

(f) $\mathrm{SCN}^{-}$

(g) $\mathrm{C} 2 \mathrm{H} 6$<smiles>CCC=O</smiles>

(i) $\mathrm{B}(\mathrm{OH})_{3}$<smiles>[O-][O+]B(O[TlH])O[TlH]</smiles>

(h) $\mathrm{C}_{2} \mathrm{H} 4$<smiles>C=C</smiles>

(j) $\mathrm{C}_{2} \mathrm{H}_{5} \mathrm{OH}$

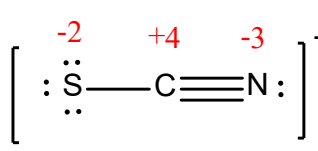<smiles>CC(C)C</smiles> 


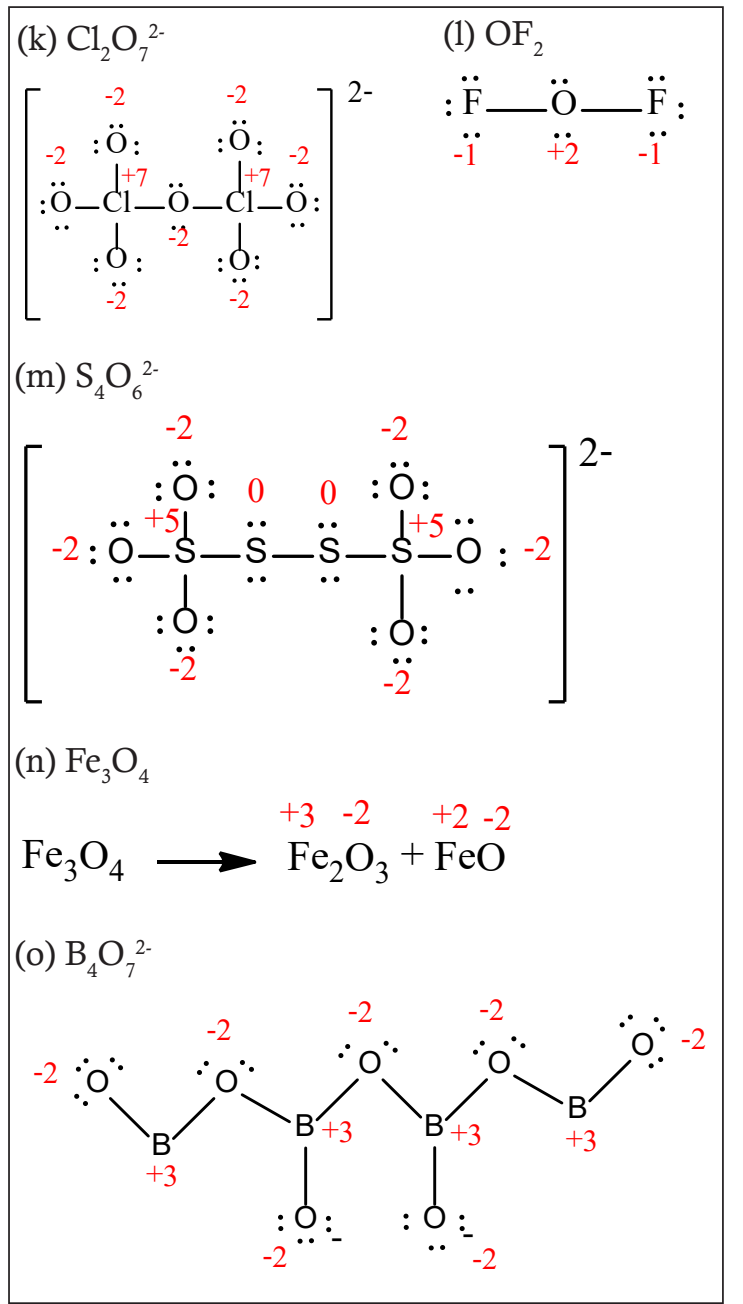

Figure 7. The Common Compound which often Mistakes in Determining the $\mathrm{ON}$

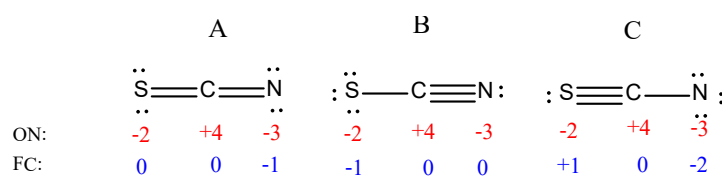

Figure 8. ON and FC of Thiocyanate Ion Resonance

The difference of the fundamental approach between $\mathrm{ON}$ and FC has important consequences: $\mathrm{ON}$ is independent; it is not depending on molecular structure (Lewis Structure). But, FC is changed depending from its Lewis structure. The Example of this phenomenon can be seen in thiocyanate ion resonance (Figure 8).

\section{CONCLUSION}

$\mathrm{ON}$ is an important concept in both elementary and advance chemistry. Learning $\mathrm{ON}$ in high school or in the beginning year in the uni- versity should be taught by the related concept: electronegativity and Lewis structure. This case study research concludes that the most of the students only know "The Rules" as initial knowledge from High School to determining oxidation number. These leads most of the students can solve Problem No. 1 and No. 2 which was simple molecules that can be solved using "The Rules". For the next problem (No.3 - No.6), less than $10 \%$ students give the correct oxidation number of an atom and none of them can explain precisely correlation among oxidation number, electronegativity, and formal charge. Learning $\mathrm{ON}$ in High School (or in the beginning year in university) should be taught by the related concept: electronegativity and Lewis structure supported by chemistry text book containing complete related concept. Without learning these connection concepts, misconceptions tend to occur and the student will struggle to learn chemistry.

\section{ACKNOWLEDGEMENTS}

The author(s) thanks Prof. Sutrisno, Ph.D as former dean of the Faculty of Science and Technology, Universitas Jambi for facilitating this work.

\section{REFERENCES}

Al-Balushi, S. M., Ambusaidi, A. K., Al-Shuaili, A. H., \& Taylor, N. (2012). Omani Twelfth Grade Students' Most Common Misconceptions In Chemistry. Science Education International, 23(3), 221-240.

Brandriet, A. R., \& Bretz, S. L. (2014). The Development of the Redox Concept Inventory as a Measure of Students' Symbolic and Particulate Redox Understandings And Confidence. Journal of Chemical Education, 91(8), 1132-1144.

Canham, J.R., \& Overton, T. (2010). Descriptive Inorganic Chemistry Fifth Edition. New York, NY: W. $\mathrm{H}$. Freeman and Company.

Chang, H. (2010). The Hidden History of Phlogiston. HYLE-International journal for philosophy of chemistry, 16(2), 47-79.

Chattaraj, P. K., \& Duley, S. (2010). Electron Affinity, Electronegativity, and Electrophilicity of Atoms and Ions. Journal of Chemical \& Engineering Data, 55(5), 1882-1886.

Diercks, C. S., \& Yaghi, O. M. (2017). The Atom, the Molecule, and the Covalent Organic Framework. Science, 355(6328), eaal1585.

Harnanto, A., \& Ruminten. (2009). Chemistry 1: for $S M A / M A$ grade $X$. Jakarta: Bookkeeping Center of the Ministry of National Education.

Jensen, W. B. (2012). When Was Electronegativity First Quantified? II. Journal of Chemical Education, 89, 94-96. 
Loock, H. P. (2010). Expanded Definition of the Oxidation State. Journal of Chemical Education, 88(3), 282-283.

Miessler, G.L., Fischer, P.J., \& Tarr, D.A. (2014). Inorganic Chemistry Fifith Edition. New York: Pearson Education, Inc.

Muchtariadi. (2016). Kimia 1 SMA Kelas X (edisi revisi 2016). Jakarta: Yudhistira.

Österlund, L. L., Berg, A., \& Ekborg, M. (2010). Redox Models in Chemistry Textbooks for the Upper Secondary School: Friend or Foe?. Chemistry Education Research and Practice, 11(3), 182-192.

Parkin, G. (2006). Valence, Oxidation Number, and Formal Charge: Three Related but Fundamentally Different Concepts. Journal of chemical education, 83(5), 791.

Permana, I. (2009). Understanding Chemistry 1: SMA/ $M A$ for grade $X 1^{\text {st }}$ and $2^{\text {nd }}$ semesters. Jakarta: Bookkeeping Center of the Ministry of National Education.

Purba, M., (2015). Chemistry 1: for SMA/MA Grade X (Specialization Group of Mathematics and Natural Sciences) K2013. Jakarta: Erlangga.

Regan, Á., Childs, P., \& Hayes, S. (2011). The Use of an Intervention Programme to Improve Undergraduate Students' Chemical Knowledge and Address their Misconceptions. Chemistry Education Research and Practice, 12(2), 219-227.

Rosenthal, D. P., \& Sanger, M. J. (2012). Student Misinterpretations and Misconceptions Based on Their Explanations of Two Computer Animations of Varying Complexity Depicting the Same Oxidation-Reduction Reaction. Chemistry Education Research and Practice, 13(4), 471483.

Schweitzer, B., \& Sukopp, T. (2018). Knowledge Communities in Europe: Discoveries of Oxygen and the "Chemical Revolution" in the Context of European Scientific Networks.

Sukopp, T. (2018). Discoveries of Oxygen and the "Chemical Revolution" in the Context of Eu- ropean Scientific Networks. In Knowledge Communities in Europe (pp. 15-47). Springer VS, Wiesbaden.

Setyawati, A.A. (2009). Chemistry studies Natural Phenomena for Grade X SMA/MA. Jakarta: Bookkeeping Center of the Ministry of National Education.

Stadler, A. M., \& Harrowfield, J. (2011). Places and Chemistry: Strasbourg-A Chemical Crucible Seen through Historical Personalities. Chemical society reviews, 40(5), 2061-2108.

Sudarmo, U., \& Sariwati, E., (2015). Students Book: Chemistry for SMA/MA Grade X (Specialization Group of Mathematics and Natural Sciences) K2013. Jakarta: Erlangga.

Sunarya, Y. (2009). Easy and Active Learning Chemistry 1: for grade X SMA/MA. Jakarta: Bookkeeping Center of the Ministry of National Education.

Taber, K. S. (2013). Revisiting the Chemistry Triplet: Drawing upon the Nature of Chemical Knowledge and the Psychology of Learning to Inform Chemistry Education. Chemistry Education Research and Practice, 14(2), 156-168.

Utami, B., Saputro, A.N.C., Mahardiani, L., Yamtinah, S., \& Mulyani, B. (2009). Chemistry 1: for $S M A / M A$ grade $X$. Jakarta: Bookkeeping Center of the Ministry of National Education.

Watoni, H., Kurniawati, D., dan Juniastri, M. (2016). Cheemistry for SMA/MA Grade X Specialization Group of Mathematics and Natural Sciences. Bandung: Yrama Widya.

Wells, A. F. (2012). Structural Inorganic Chemistry. Oxford University Press.

Widarti, H. R., Permanasari, A., \& Mulyani, S. (2016). Student Misconception on Redox Titration (A Challenge on the Course Implementation through Cognitive Dissonance based on the Multiple Representations). Jurnal Pendidikan IPA Indonesia, 5(1), 56-62.

Weisberg, M., Needham, P., \& Hendry, R. (2011). Philosophy of chemistry. 